\title{
Harris Hip Score and SF-36 following metal- on-metal total hip arthroplasty and hip resurfacing - a randomized controlled trial with 5-years follow up including 75 patients
}

Peter Nyby Hersnaes* ${ }^{*}$, Kirill Gromov, Kristian Stahl Otte, Peter Henrik Gebuhr and Anders Troelsen

\begin{abstract}
Background: The metal-on-metal large-diameter-head (MoM-LDH) hip replacements increased in popularity during the start of the twenty-first century. Subsequently reports raised concerns regarding adverse reactions due to elevated chromium (Cr) and cobalt (Co) concentrations as well as high rates of other complications and revisions. The purpose was to compare Harris Hip Score and SF-36 at 5-years follow up following MoM-LDH total hip arthroplasty (MoM-LDH-THA) or MoM hip resurfacing (MoM-HR).
\end{abstract}

Methods: The study was conducted between November 2006 to January 2012 in a tertiary health care center in Denmark. Patients with primary or secondary osteoarthritis were randomly assigned to receive a Magnum (MoMLDH-THA) or a Recap (MoM-HR) prosthesis. Randomization was computer generated and allocation was concealed in an opaque envelope. Neither patients nor care provider were blinded. Primary outcome was Harris Hip Score at 5-years follow up.

Results: Seventy-five were included and allocated to the MoM-LDH-THA $(n=39)$ and MoM-HR $(n=36)$ group. The study was prematurely stopped due to numerous reports of adverse events in patients with MoM hip replacements. Thirty-three in the MoM-LDH-THA and 25 in the MoM-HR group were available for primary outcome analysis.

Median Harris Hip Score was 100 (IQR: 98-100) for MoM-LDH-THA and 100 (IQR: 93-100) for MoM-HR ( $p=0.486)$. SF-36 score was high in both groups with no significant difference between groups.

Conclusion: Harris Hip Score and SF-36 score was excellent in both groups with no significant difference at 5-years follow up. Our findings suggest that there is no clinical important difference between the two prostheses implanted 5 years after implantation.

Trial registration: ClinicalTrials.gov, NCT04585022, Registered 23 September 2020 - Retrospectively registered. This study was not prospectively registered in a clinical trial database since it was not an entirely implemented standard procedure in the international orthopedic society when the study was planned.

\footnotetext{
*Correspondence: pnhersnaes@gmail.com

Department of Orthopaedic Surgery, Copenhagen University Hospital

Hvidovre, Hvidovre, Denmark
}

(c) The Author(s). 2021 Open Access This article is licensed under a Creative Commons Attribution 4.0 International License, which permits use, sharing, adaptation, distribution and reproduction in any medium or format, as long as you give appropriate credit to the original author(s) and the source, provide a link to the Creative Commons licence, and indicate if changes were made. The images or other third party material in this article are included in the article's Creative Commons licence, unless indicated otherwise in a credit line to the material. If material is not included in the article's Creative Commons licence and your intended use is not permitted by statutory regulation or exceeds the permitted use, you will need to obtain permission directly from the copyright holder. To view a copy of this licence, visit http://creativecommons.org/licenses/by/4.0/ The Creative Commons Public Domain Dedication waiver (http://creativecommons.org/publicdomain/zero/1.0/) applies to the data made available in this article, unless otherwise stated in a credit line to the data. 
Keywords: Hip replacement arthroplasty, Total hip arthroplasty, Hip resurfacing, Osteoarthritis, Harris hip score, SF36, Metal ion concentration

\section{Background}

During the start of the twenty-first century the use of metal-on-metal large-diameter-head total hip arthroplasty (MoM-LDH-THA) and metal-on-metal hip resurfacing (MoM-HR) increased rapidly. Proposed advantages over the conventional small-head metal-onpolyethylene articulation were low wear of implant, increased range of motion and reduced dislocation rates [1-4]. Subsequently reports in the 2010s raised concerns regarding association between elevated metal ion concentration in blood and locally as well as systemic complications in patients with MoM hip implants [5-7]. The use of MoM implants declined worldwide after international regulatory agencies issued alerts and safety communications related to the use of MoM hip implants [8-10]. Local complications due to metal wear from MoM hip implants are broadly referred to as adverse reaction to metal debris (ARMD) and includes joint failures associated with pain, large sterile effusion of the hip and macroscopic metallosis [11].

It has been estimated that over one million patients worldwide have received a MoM hip implant [12]. Identifying risk factors associated with high metal ion concentrations in patients who have received a MoM hip implant as well as whether or not there is a medium to long term clinical difference between MoM implant designs is therefore of great importance.

We aimed to investigate the possible differences in Harris Hip Score and SF-36 in patients following single brand MoM-HR or single brand MoM-LDH-THA as well as radiological findings, metal ion concentrations and rate of revision at 5 -years follow up.

We hypothesize that there is no clinical difference in Harris Hip Score and SF-36 when comparing patients receiving MoM-LDH-THA and MoM-HR 5 years after primary surgery.

\section{Methods}

\section{Study design}

This was a single center parallel-group randomized controlled trial. We compared outcome between groups at 5 -years follow up.

Perceived hip function was the primary outcome measured with Harris Hip Score at 5-years follow up.

Secondary outcomes were SF-36, metal ion concentrations $(\mathrm{Cr}$ and $\mathrm{Co})$, radiological findings and revision rate at 5-years follow up. The study was planned and started before the association between elevated blood metal ions and complications in patients with MoM hip implants was known. The study was prematurely terminated in 2012 due to alerts and safety communications from the Danish national regulatory agency regarding early failure rates and high incidence of ARMD in patients with MoM hip implants [13]. At that time the study population consisted of 75 patients out of 200 planned for inclusion.

\section{Subjects}

The study was conducted in a tertiary health care center in Copenhagen, Denmark from November 2006 to January 2012. 5-years follow up consultations were conducted from 2011 to 2017. Eligible patients were men aged 18 to 70 and women aged 18 to 65 suffering from primary or secondary hip osteoarthritis eligible for hip replacement surgery according to guidelines at the department at that time. Understanding and speaking $\mathrm{Da}$ nish, able to give informed consent and able to complete follow up consultations were obligatory.Exclusion criteria were earlier or present infection of the hip, severe systemic or metabolic disease leading to weakening of the bone, severe congenital hip dysplasia, osteoporosis and renal disease.

\section{Randomization and allocation}

All patients were randomly allocated to receive either a Magnum (Zimmer Biomet, Warsaw, IN) or a Recap (Zimmer Biomet, Warsaw, IN) implant. A computer program was used for randomly generating an allocation sequence and allocation was concealed in an opaque envelope until the day of surgery. Neither patients nor care provider were blinded. The laboratory analyzing blood metal concentrations were blinded to treatment allocation throughout the study.

\section{Surgical procedure and recovery}

Two experienced surgeons performed the surgeries through a standard posterolateral approach in both groups. The MoM-LDH-THA prosthesis included the uncemented Bimetric Hip Primary Femoral Porous coated collarless stem, the M2a Magnum Taper Adaptor and the M2a Magnum Modular Head. The MoM-HR prosthesis included the cemented (Refobacin Bone Cement, Zimmer Biomet, Warsaw, IN) Recap Resurfacing System Femoral Head. The uncemented Recap/Magnum Acetabular Shell was used in both groups. Pre- and postoperative $\mathrm{x}$-ray images are seen in Fig. 1 (preoperative), Fig. 2 (MoM-LDH-THA) and Fig. 3 (MoM-HR). The standard techniques for insertion as imposed by the 


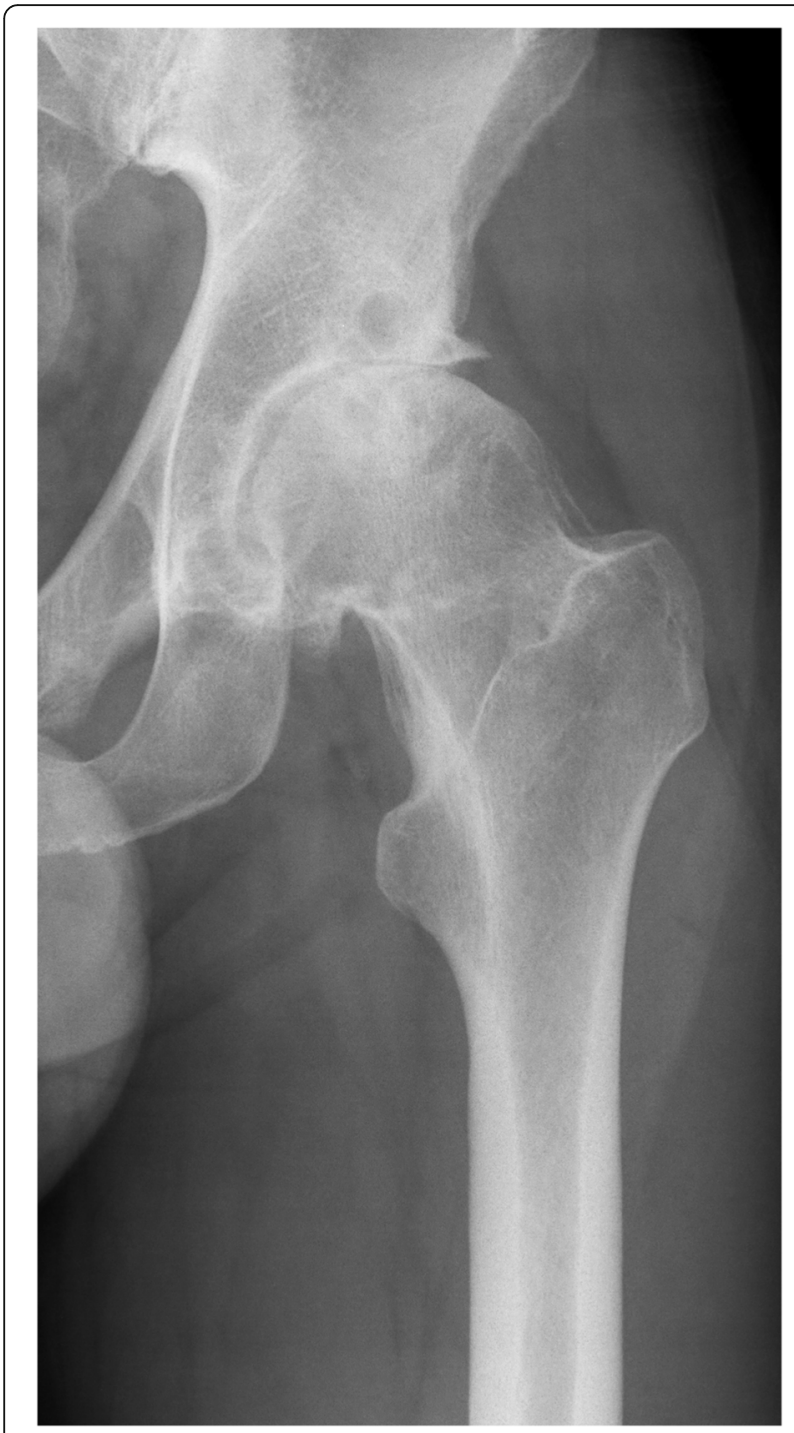

Fig. 1 Preoperative $x$-ray of severe osteoarthritis

manufacturer was followed. Both groups received the same standardized thromboprophylactic and prophylactic antibiotic treatment. The two groups followed the same standardized postoperative rehabilitation plan allowing immediate weight bearing as tolerated and physiotherapy starting from day of surgery and continued after discharge as outpatient rehabilitation.

\section{Outcome evaluation}

\section{Patient reported outcome measure}

Harris Hip Score was used for measuring hip function. Scoring was based on the instruction by Mahomed et al. [14] with the following alterations : 1) The question addressing public transportation was included and 2) All participants received 4 points indicating no fixed deformity or limb length discrepancy of $3.2 \mathrm{~cm}$ or more.

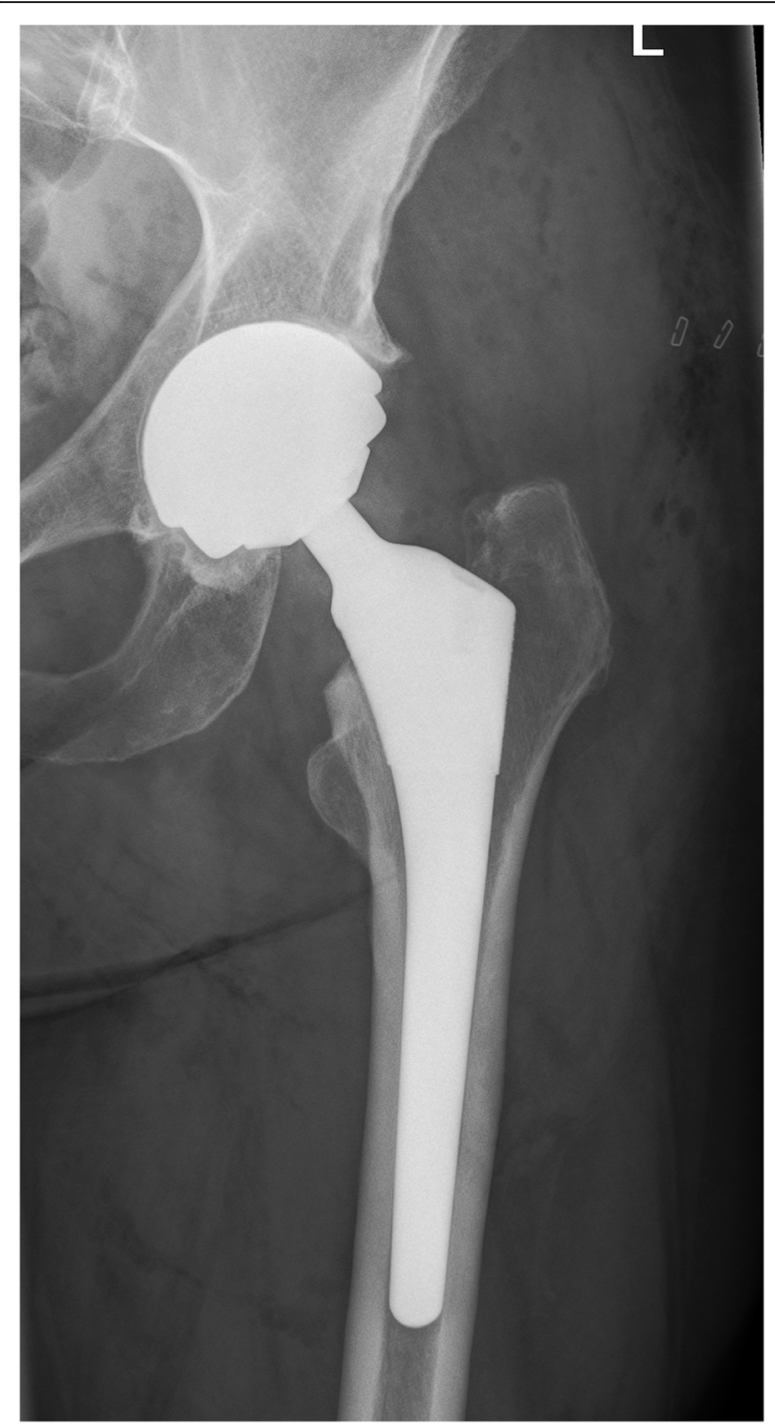

Fig. 2 Postoperative x-ray (MoM-LDH-THA)

SF-36 version 1 was used for measuring quality of life. Scoring was based on the original manual "SF-36 Health Survey Manual \& Interpretation Guide” [15]. Median values were used when interpreting PROM scores. Score range was $0-100$ for both questionnaires with high scores indicating good perceived hip function and quality of life respectively.

\section{Metal ion measurement}

Chromium and cobalt concentrations were measured in whole blood using an inductively coupled plasma sector field mass spectrometer (ICP-SFMS) on the Thermo Fischer ELEMENT 2 (Thermo Fisher Scientific Inc. Waltham, MA).

Patients with bilateral MoM hip implants at 5-years follow up were excluded from metal ion analysis. 


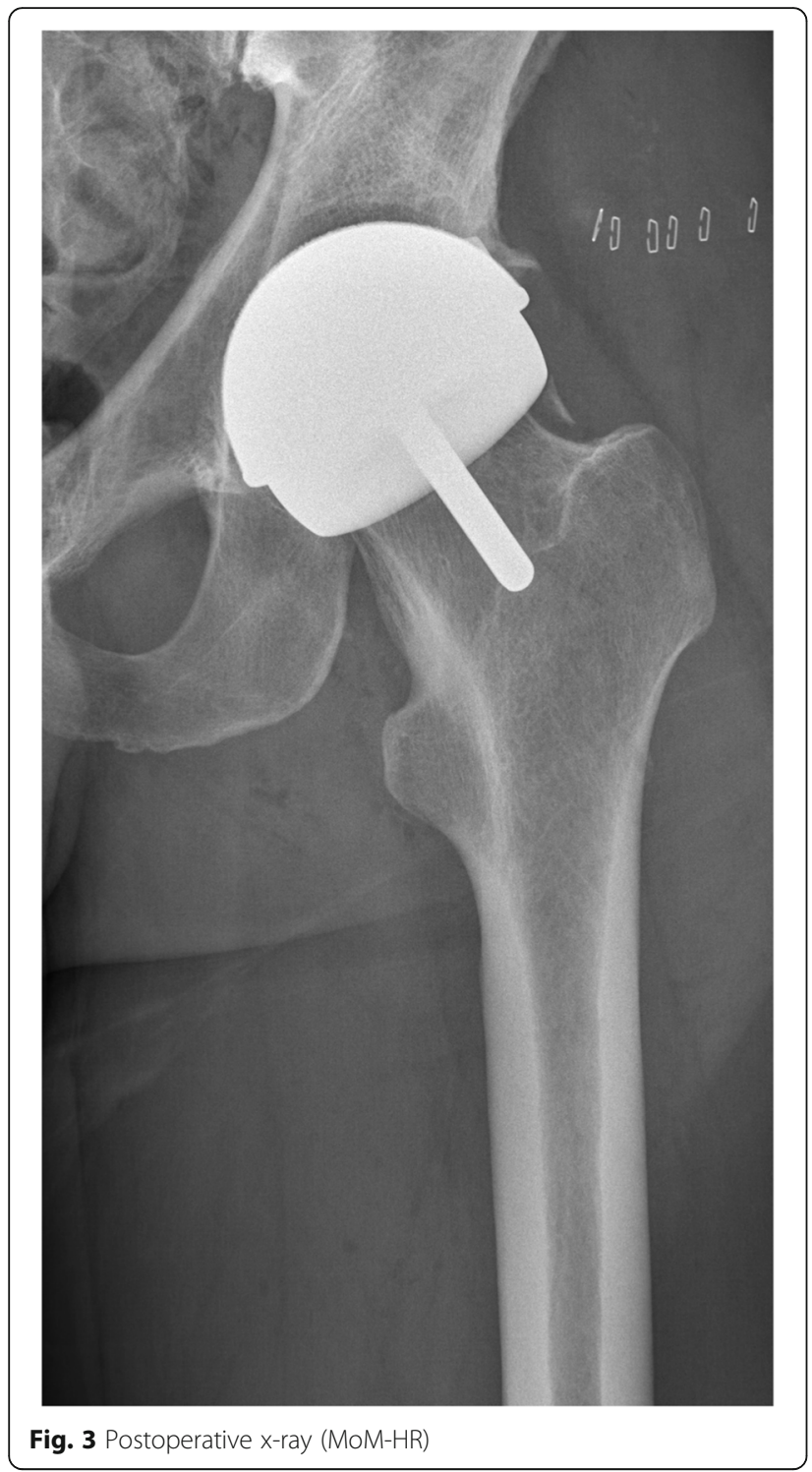

Radiological analyses

Radiolucency and osteolysis Radiological analysis for radiolucency and osteolysis was done with the software mDESK $^{\mathrm{TM}}$ version 3.6.7.0 (RSA Biomedical, Umeaa, Sweden). The acetabular component in both groups was analyzed for radiolucency as described by DeLee and Charnley [16]. In the MoM-LDH-THA group the stem was analyzed for radiolucency as described by Gruen et al. [17]. Radiolucency $>2 \mathrm{~mm}$ was considered pathological. All radiological analyses were performed by an orthopedic surgeon under training. In case of doubt consensus was achieved after consulting with a senior colleague.

Inclination angle and version Cup inclination angle and degree of anteversion were measured using Martell's
Hip Analysis Suite version 8.0.4.3 (University of Chicago, Chicaco, IL). Analyses were conducted on calibrated anteroposterior pelvic radiographs. In hips with an estimated anteversion equal or lesser than 10 degrees $(n=$ 29) a shoot-through lateral radiograph was analyzed for ante- or retroversion as done by Callanan et al. [18].

\section{Implant survival}

Patients undergoing revision before 5-years follow up were identified. Date as well as reason for revision were registered. Cross-sectional imaging was performed when indicated in accordance to the national guidelines from the Danish Orthopaedic Society [19].

\section{Statistical analysis}

All statistical analyses were performed using the statistical software RStudio version 1.0.153 (RStudio, Inc., Boston, MA, URL http://www.rstudio.com). Comparisons between groups were performed using Wilcoxon Rank Sum test for non-parametric numerical data and Pearson's Chi-squared test for non-parametric ordinal data. A $p$-value $<0.05$ was considered significant.

\section{Power analysis}

The original sample size calculation estimated that 100 patients in each group would be needed to detect a 3point difference between groups in a 2 -sided significance test with a power of 0.8 and an alpha error level of 0.05 when assuming a standard deviation of 7 points in Harris Hip Score and a dropout rate of $15 \%$.

\section{CONSORT statement}

This study adheres to CONSORT guidelines.

\section{Results}

\section{Baseline demographics}

Total median age was 61.9 years in the MoM-LDH-THA group and 59.4 years in the MoM-HR group. Gender ratio $(\mathrm{M} / \mathrm{F})$ was 2.00 in the MoM-LDH-THA group and 2.60 in the MoM-HR group. All baseline demographics are shown in Table 1.

\section{Patient flow}

A CONSORT Flow Diagram is presented in Fig. 4. Regarding secondary outcomes: 25 patients in the MoMLDH-THA group and 20 patients in the MoM-HR group were available for metal ion concentration analysis at 5-years follow up excluding bilateral MoM hip replacement, lost to follow up, revision or died before 5years follow up. 
Table 1 Baseline demographics

\begin{tabular}{|c|c|c|c|c|c|}
\hline & & $\begin{array}{l}\text { Total } \\
n=75 \\
\text { (1st - 3rd quartile) }\end{array}$ & $\begin{array}{l}\text { MoM-LDH-THA } \\
n=39 \\
\text { (1st - 3rd quartile) }\end{array}$ & $\begin{array}{l}\text { MoM-HR } \\
n=36 \\
\text { (1st - 3rd quartile) }\end{array}$ & $p$-value \\
\hline \multirow[t]{3}{*}{ Median age } & Total & $60.8(54.55-63.3)$ & $61.9(56.5-63.2)$ & $59.4(51.2-63.58)$ & 0.107 \\
\hline & Males & $61.95(55.62-64.83)$ & $62.65(60.65-64.88)$ & $60.35(53.60-64.40)$ & 0.253 \\
\hline & Females & $58.40(53.00-61.00)$ & $59.40(55.40-62.30)$ & $53.00(50.92-59.75)$ & 0.088 \\
\hline \multicolumn{2}{|c|}{ Gender ratio (M/F) } & 2.26 & 2.00 & 2.60 & 0.79 \\
\hline \multicolumn{2}{|l|}{ Median BMI } & $27.9(25.2-31.0)$ & $28.4(25.8-28.93)$ & $27.45(24.6-29.32)$ & 0.12 \\
\hline
\end{tabular}

\section{CONSORT 2010 Flow Diagram}

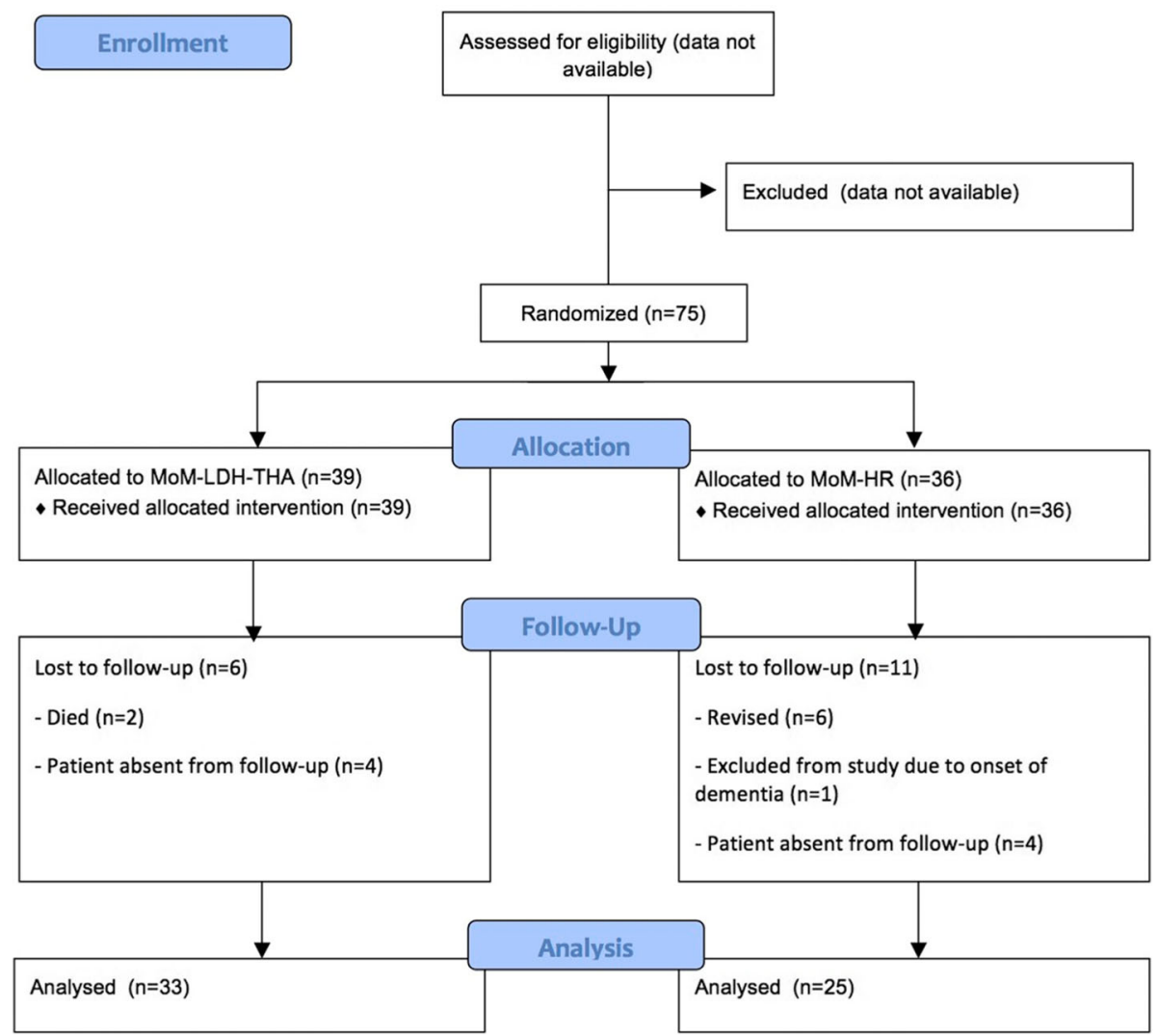

Fig. 4 Consort diagram illustrating flow of patients during enrollment, allocation, follow up and analysis 


\section{Head size}

Median (IQR) head diameter was 48 (46-50) and 50 (47.5-52) in the MoM-LDH-THA and MoM-HR group respectively $(p=0.13)$.

\section{Cup inclination and version}

Median cup inclination angle was $40.94^{\circ}$ IQR $\left(35.28^{\circ}\right.$ $\left.47.06^{\circ}\right)$ in the MoM-LDH-THA group and $43.05^{\circ}$ IQR $\left(35.91^{\circ}-46.06^{\circ}\right)$ in the MoM-HR group $(p=0.94)$. Median cup anteversion was $12.24^{\circ} \operatorname{IQR}\left(5.79^{\circ}-17.69^{\circ}\right)$ in the MoM-LDH-THA group and $12.34^{\circ}$ IQR $\left(5.35^{\circ}-16.89^{\circ}\right)$ in the MoM-HR group $(p=0.84)$.

\section{Patient reported outcome measures}

Both median Harris Hip Score and median SF-36 subset scores were high in the two groups. No significant differences in Harris Hip Score or SF-36 subset scores were found between the two groups (Table 2). No baseline data were obtained since the aim of the study was to compare scores between groups at 5 years follow up and not to compare paired data. We are confident that the randomization design of the study protects against any significant difference in preoperative scores between groups.

\section{Cobalt and chromium concentrations}

Median chromium concentration was $1.36 \mu \mathrm{g} / \mathrm{L}$ in the MoM-LDH-THA group and $1.21 \mu \mathrm{g} / \mathrm{L}$ in the MoM-HR $(p=0.46)$. Median cobalt concentration was $1.67 \mu \mathrm{g} / \mathrm{L}$ in the MoM-LDH-THA group and $0.92 \mu \mathrm{g} / \mathrm{L}$ in the MoMHR group ( $p=0.073)$ (Table 3$)$.

The lower detection limit for metal ion concentration was $0.5 \mu \mathrm{g} / \mathrm{L}$. In three cases, all in the MoM-HR group, chromium concentrations were below this limit and an estimated concentration of $0.25 \mu \mathrm{g} / \mathrm{L}$ was used.

The very first blood analysis determined cobalt and chromium concentrations to be $<7.0 \mu \mathrm{g} / \mathrm{L}$ with no further specification. The analyses were made on a different instrument than all the subsequent blood analyses and were excluded. This incident only lead to exclusion of 1 patient from metal ion concentration analysis with limited impact on estimates.

\section{Radiological findings}

No radiolucency was found in any patient. One case of osteolysis was seen in the MoM-HR group 2 years after surgery and revision was done. Revision surgery was done and septic loosening was diagnosed after cultivation of Staphylococcus epidermidis in 4 out of 6 tissue samples.

\section{5 -years revision rates}

5 -years revision rate was $0 \%$ in the MoM-LDH-THA group and $16.7 \%(n=6)$ in the MoM-HR group. The causes for revision were facture of the femoral neck $(n=2)$, aseptic loosening of cup $(n=1)$, unexplained hip pain without joint failure $(n=1), \operatorname{ARMD}(n=1)$ and septic loosening $(n=1)$.

\section{Discussion}

Both the MoM-LDH-THA and the MoM-HR group showed excellent PROM scores at 5-years follow up. Median SF-36 subset scores was equal or even better compared to the Danish background population [20]. Neither Harris Hip Scores nor any SF-36 subset scores varied significantly between the two groups.

Table 2 Patient reported outcome measure scores at 5-years follow up

\begin{tabular}{|c|c|c|c|c|c|}
\hline & & $\begin{array}{l}\text { Total (1st - 3rd } \\
\text { quartile) }\end{array}$ & $\begin{array}{l}\text { MoM-LDH-THA (1st - 3rd } \\
\text { quartile) }\end{array}$ & $\begin{array}{l}\text { MoM-HR (1st - 3rd } \\
\text { quartile) }\end{array}$ & $\begin{array}{l}p \text { - } \\
\text { value }\end{array}$ \\
\hline Median Harris Hip Score & & $\begin{array}{l}100(96-100) \\
n=58\end{array}$ & $\begin{array}{l}100(98-100) \\
n=33\end{array}$ & $\begin{array}{l}100(93-100) \\
n=25\end{array}$ & 0.486 \\
\hline \multirow[t]{8}{*}{$\begin{array}{l}\text { Median SF-36 Subset } \\
\text { Score }\end{array}$} & Physical function & $\begin{array}{l}90(70-95) \\
n=53\end{array}$ & $\begin{array}{l}90(68.75-95) \\
n=28\end{array}$ & $\begin{array}{l}90(70-100) \\
n=25\end{array}$ & 0.843 \\
\hline & Physical restriction & $\begin{array}{l}100(66.67-100) \\
n=53\end{array}$ & $\begin{array}{l}100(72.92-100) \\
n=28\end{array}$ & $\begin{array}{l}100(50-100) \\
n=25\end{array}$ & 0.512 \\
\hline & Bodily pain & $\begin{array}{l}84(62-100) \\
n=56\end{array}$ & $\begin{array}{l}92(62-100) \\
n=30\end{array}$ & $\begin{array}{l}84(62-100) \\
n=26\end{array}$ & 0.629 \\
\hline & General health & $\begin{array}{l}77(57-87.75) \\
n=52\end{array}$ & $\begin{array}{l}74.5(61.75-89.25) \\
n=26\end{array}$ & $\begin{array}{l}79.5(56.44-87.00) \\
n=26\end{array}$ & 0.57 \\
\hline & Vitality & $\begin{array}{l}75(50-85) \\
n=54\end{array}$ & $\begin{array}{l}77.5(60-85) \\
n=28\end{array}$ & $\begin{array}{l}75(32.5-85) \\
n=26\end{array}$ & 0.674 \\
\hline & Social function & $\begin{array}{l}100(100-100) \\
n=55\end{array}$ & $\begin{array}{l}100(100-100) \\
n=29\end{array}$ & $\begin{array}{l}100(100-100) \\
n=26\end{array}$ & 0.991 \\
\hline & $\begin{array}{l}\text { Emotional } \\
\text { restriction }\end{array}$ & $\begin{array}{l}100(100-100) \\
n=53\end{array}$ & $\begin{array}{l}100(100-100) \\
n=28\end{array}$ & $\begin{array}{l}100(100-100) \\
n=25\end{array}$ & 0.411 \\
\hline & Mental Health & $\begin{array}{l}90(72-96) \\
n=52\end{array}$ & $\begin{array}{l}92(72-96) \\
n=27\end{array}$ & $\begin{array}{l}88(76-92) \\
n=25\end{array}$ & 0.4 \\
\hline
\end{tabular}


Table 3 Whole blood metal ion concentrations at 5-years follow up

\begin{tabular}{|c|c|c|c|c|c|}
\hline & & $\begin{array}{l}\text { Total (1st }-3 r d \\
\text { quartile) }\end{array}$ & $\begin{array}{l}\text { MoM-LDH-THA (1st - 3rd } \\
\text { quartile) }\end{array}$ & $\begin{array}{l}\text { MoM-HR (1st - 3rd } \\
\text { quartile) }\end{array}$ & $\begin{array}{l}p- \\
\text { value }\end{array}$ \\
\hline \multirow[t]{2}{*}{$\begin{array}{l}\text { Median whole blood metal ion } \\
\text { concentrations }(\mu \mathrm{g} / \mathrm{L})\end{array}$} & Chromium & $\begin{array}{l}1.35(0.96-3.11) \\
n=45\end{array}$ & $\begin{array}{l}1.36(0.99-3.11) \\
n=25\end{array}$ & $\begin{array}{l}1.21(0.88-3.03) \\
n=20\end{array}$ & 0.46 \\
\hline & Cobalt & $\begin{array}{l}1.11(0.69-2.15) \\
n=45\end{array}$ & $\begin{array}{l}1.67(0.86-2.31) \\
n=25\end{array}$ & $\begin{array}{l}0.92(0.64-1.49) \\
n=20\end{array}$ & 0.073 \\
\hline
\end{tabular}

In this report of a prematurely terminated randomized controlled trial with 75 patients included we assessed and compared Harris Hip Score and SF-36 between a single brand MoM-LDH-THA $(n=33)$ and a single brand MoM-HR $(n=25)$ as well as whole blood metal ion concentrations, radiological findings and revision rate at 5-years follow up.

Similar to our study Borgwardt et al. [21] found no significant difference between the Magnum and the Recap group in Harris Hip Score at 5-years follow up. Regarding SF-36 no 5-years follow up results were reported but a significantly lower score in 3 out of 8 subsets were reported at 7-years follow up in the Recap group compared to the Magnum and the ceramic-onceramic group.

Costa et al. [22] conducted a randomized controlled trial with 122 patients. All HR implants had MoM bearings while bearing material in the THA group included both ceramic-on-ceramic, ceramic-on-metal and metalon-metal. No significant difference in Harris Hip Score between HR and THA was found 1 year after surgery.

Garbuz et al. [23] conducted a randomized controlled trial with 104 patients receiving either the Durom resurfacing component $(n=48)$ or the M/L Taper stem $(n=$ $56)$. Both groups received the same Durom acetabular cup. Similar to Costa et al. no difference was shown regarding SF-36 between groups 1 year after surgery.

We found raised whole blood metal ion concentrations in both groups with a close to significantly higher median cobalt concentration in the MoM-LDH-THA group $(1.67 \mu \mathrm{g} / \mathrm{L})$ compared to the MoM-HR group $(0.92 \mu \mathrm{g} / \mathrm{L})$ $(p=0.073)$. No significant difference in median chromium concentration between the MoM-LDH-THA group $(1.36 \mu \mathrm{g} / \mathrm{L})$ and the MoM-HR group $(1.21 \mu \mathrm{g} / \mathrm{L})$ was found $(p=0.46)$. Despite raised metal ion concentrations was found in both groups we do not suspect concentrations in this range to be of any clinical significance in either of the groups. However we believe that these findings indicate a need for longer than 5 years follow up period in terms of measuring blood metal ion concentration especially in patients with MoM-LDHTHA.

Intravascular metal ion concentrations are measured in either serum or whole blood. Absolute values of chromium and cobalt in serum and whole blood are not comparable but it should be noted that intrapersonal cobalt and chromium concentrations are higher in serum compared to whole blood [24].

To our knowledge only a few studies comparing metal ion concentrations between MoM-LDH-THA and MoM-HR at 5-years follow up or longer exist.

In a randomized controlled trial [21] comparing the Magnum $(n=36)$, Recap $(n=41)$ and a ceramic-onceramic $(n=49)$ implant significantly higher serum cobalt concentrations were found in the Magnum group (median $2.10 \mu \mathrm{g} / \mathrm{L}$ ) compared to the Recap group (median $1.12 \mu \mathrm{g} / \mathrm{L})$ at 5 -years follow up $(p=0.029)$. Concurrently no differences in serum chromium concentrations were found.

In a systematic review [25] on $\mathrm{Cr}$ and Co concentrations in multiple MoM implants (both THA and HR) a peak concentration was calculated after a minimum of 1-year follow up. Median whole blood Co values ranged between 0.7 and $2.7 \mu \mathrm{g} / \mathrm{L}$ while median whole blood $\mathrm{Cr}$ values ranged between 0.5 and $2.5 \mu \mathrm{g} / \mathrm{L}$. Our results from both the MoM-LDH-THA and MoM-HR group for both median Co and $\mathrm{Cr}$ values lies in the mid part of the ranges. It should be noted that our median values are from one point in time while the systematic review reported maximum metal ion concentrations from different points in time.

In a retrospective comparative study [26] of 77 well functioning Birmingham MoM-HRs and 42 well functioning Birmingham MoM-LDH-THAs both paired with the same BHR cup a significantly higher mean serum cobalt concentration at a mean follow up time of 39.3 months was found in the MoM-LDH-THA group $(2.75 \mu \mathrm{g} / \mathrm{L})$ compared to the MoM-HR group $(1.52 \mu \mathrm{g} / \mathrm{L})(p<0.001)$. Similar to our study no significant difference in chromium concentrations was found in the study.

Taking the above into account it seems that both the MoM-LDH-THA and MoM-HR implant used in our study are in the lower range regarding metal ion concentrations at mid-term follow up when comparing with other brands with similar design. Additionally, Hutt et al. [27] found the lowest whole blood cobalt and chromium concentrations in the Magnum implant when comparing with three other types of MoM-LDH-THA (Durom, Birmingham, ASR XL) at 5-years follow up with differences between Magnum and Durom or Birmingham being significant. 
There is a difference regarding wear and corrosion between MoM-LDH-THA and MoM-HR. While both implant types have identical MoM bearings it is well known that the head-neck junction in the MoM-THA is an additional source of metal ion release [28]. In LDHTHA a trunnion is often used to connect the head and neck resulting in trunnion corrosion leading to additional release of metal ions. A recent systematic review [29] revealed higher rate of trunnion corrosion in mixed metal alloys at the head-neck junction compared to head-neck junctions with similar metal alloys due to galvanic corrosion. The trunnion in the MoM-LDH-THA implant in our study was made of a titanium alloy.

The 5 -years revision rate was $0 \%$ in the MoM-LDHTHA group and $16.67 \%(n=6)$ in the MoM-HR group. One revision (ARMD) was related to the concept of MoM articulation while two revisions (fracture of the femoral neck) were related to HR design. Our findings are not similar to previous studies findings.

In the before mentioned randomized controlled trial comparing Magnum, Recap and a ceramic-on-ceramic implant [30] 7-years revision rate was 3.9\% $(n=2)$ in the Recap and $4.3 \%(n=2)$ in the Magnum group.

In a Scandinavian register study [31] $(n=32,678)$ they compared midterm revision rates between THA with either MoM or metal-on-polyethylene (MoP) bearings as well as revision rates between different MoM-THA designs. The cumulative incidence of revision in the MoM-THA with the ASR acetabular component was more than $25 \%$ at 5.8 years. When excluding the ASR acetabular component they found an 8-years revision risk of $5.0 \%$ in the MoM-THA. When comparing specific cup and stem combinations a significantly higher $R R$ of revision was seen in the M2a/Bi-metric, ASR/Summit and ASR/Corail compared to the Recap/Bi-metric combination. No difference in RR between MoM-THA and MoP-THA was found when excluding the ASR acetabular components. To some extend this could explain why the MoM-LDH-THA group in our study, which had a Recap acetabular component, had a very low 5-years rate of revision.

A Finnish nationwide register study [32] reported significantly higher revision risk in the ASR/Corail THA compared to the ASR HR ( $R R=0.73, p=0.04)$ while no significant revision risk was found between the Recap/ Bi-metric THA and Recap HR or the Synergy/BHR THA and BHR resurfacing.

In a registry report [33] comparing revision rates for Birmingham MoM-HR $(n=8453)$ and Birmingham MoM-LDH-THA $(n=2101)$ 5-years revision rate was $3.2 \%$ in the MoM-HR group and $4.9 \%$ in the MoMLDH-THA group with no significant difference between groups.
Despite the lack of power it is noticeable that the revision rate in the MoM-HR group in our study was higher than in all the studies mentioned while the revision rate in the MoM-LDH-THA group was lower than in all the studies mentioned.

Our study has some limitations. Due to a revision rate of $16.7 \%$ in the MoM-HR group and lost at follow up (15.4 and 13.9\% for MoM-LDH-THA and MoM-HR respectively) in both groups data were not complete. No preoperative data were obtained for our primary or secondary outcomes. This is a limitation in means of data comparison between groups postoperatively. However we consider it safe to assume that no preoperative difference in Harris Hip score or SF-36 were present considering that there was no significant difference in baseline demographics and due to the randomization design of the study. We also consider it safe to assume that no preoperative difference in whole blood metal ion concentrations were present between the two groups as we excluded patients who had a contralateral MoM hip implant at day of surgery. One must assume that patients without a MoM articulating hip implant have very low amounts of cobalt and chromium in the blood. Our findings could not demonstrate any significant difference in Harris Hip Score nor SF-36 subset scores. However due to premature termination of the study it lacks power causing a risk of type II error. Therefore our findings must be interpreted with caution.

Despite the lack of power our results demonstrate a tendency towards higher metal ion concentrations in the MoM-LDH-THA group compared to the MoM-HR group which is in accordance to other studies findings $[26,30]$.

\section{Conclusion}

Harris Hip Score and SF-36 scores were excellent in both groups with no significant difference at 5 -years follow up. Our findings suggest that there is no clinical important difference between the two prostheses implanted 5 years after implantation. However due to lack of power our findings must be interpreted with caution. Whole blood metal ion concentrations were similar following MoM-LDH-THA and MoM-HR implantation at 5-years follow up. Cobalt concentration was close to being significantly higher in the MoM-LDH-THA group while no significant difference was found in chromium concentrations between the two groups. We found a high 5-year revision rate of $16.7 \%$ in the MoM-HR group and a low 5 -year revision rate of $0 \%$ in the MoM-LDH-THA.

\section{Abbreviations}

MoM-LDH: Metal-on-metal large diameter head; Cr: Chromium; Co: Cobalt; THA: Total hip arthroplasty; HR: Hip resurfacing; IQR: Interquartile range; ARMD: Adverse reaction to metal debris; ICP-SFMS: Inductively coupled 
plasma sector field mass spectrometer; PROM: Patient reported outcome measure

\section{Acknowledgements}

Not applicable.

\section{Authors' contributions}

All authors have read and approved the manuscript. PNH: Main author. Planned the study, collected data, performed data analysis, drafted and revised the paper. KG: Supervised the data collection and revised the paper. KO: Performed surgeries and revised the paper. PG: Planned the study, performed surgeries and revised the paper. AT: Planned the study, supervised the data collection and revised the paper.

\section{Funding}

This research did not receive any specific grant from funding agencies in the public, commercial, or not-for-profit sectors.

\section{Availability of data and materials}

The datasets used and analyzed during the current study are available from the corresponding author on reasonable request.

\section{Declarations}

\section{Ethics approval and consent to participate}

The study was approved by the Ethical Committee of Copenhagen June 21, 2006 as protocol KF 01-309171. Written consent was obtained from all participants prior to inclusion in the study.

\section{Consent for publication}

Not applicable.

\section{Competing interests}

The authors declare that they have no competing interests.

Received: 17 November 2020 Accepted: 31 August 2021

Published online: 12 September 2021

\section{References}

1. Schmalzried TP, Peters PC, Maurer BT, Bragdon CR, Harris WH. Long-duration metal-on-metal total hip arthroplasties with low wear of the articulating surfaces. J Arthroplast. 1996;11(3):322-31. https://doi.org/10.1016/50883-54 03(96)80085-4.

2. Chan FW, Bobyn D, Medley JB, Krygier JJ, Tanzer M. Wear and lubrication of metal-on-metal hip implants. Clin Orthop Relat Res. 1999;369:10-24. https:// doi.org/10.1097/00003086-199912000-00003.

3. Cuckler JM, Moore KD, Lombardi AV, McPherson E, Emerson R. Large versus small femoral heads in metal-on-metal total hip arthroplasty. J Arthroplast. 2004;19(8):41-4. https://doi.org/10.1016/j.arth.2004.09.006.

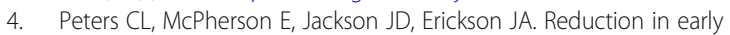
dislocation rate with large-diameter femoral heads in primary Total hip arthroplasty. J Arthroplast. 2007;22(6):140-4. https://doi.org/10.1016/j.arth.2 007.04.019.

5. Papageorgiou I, Yin Z, Ladon D, Baird D, Lewis AC, Sood A, et al. Genotoxic effects of particles of surgical cobalt chrome alloy on human cells of different age in vitro. Mutat Res - Fundam Mol Mech Mutagen. 2007;619(12):45-58. https://doi.org/10.1016/j.mrfmmm.2007.01.008.

6. Langton DJ, Joyce TJ, Jameson SS, Lord J, Van Orsouw M, Holland JP, et al. Adverse reaction to metal debris following hip resurfacing: the influence of component type, orientation and volumetric wear. J Bone Jt Surg - Br Vol. 2011;93-B(2):164-71. https://doi.org/10.1302/0301-620X.93B2.25099.

7. Whitehouse MR, Aquilina AL, Patel S, Eastaugh-Waring SJ, Blom AW. Survivorship, patient reported outcome and satisfaction following resurfacing and total hip arthroplasty. J Arthroplast. 2013;28(5):842-8. https://doi.org/10.1016/j.arth.2013.01.007.

8. Medicines and Healthcare Products Regulatory Agency. Medical device alert. All metal-on-metal (MoM) hip replacements: updates advice for follow-up of patients; 2017. p. 1-6.

9. U.S. Food and Drug Administration. Metal-on-metal hip implants - concerns about metal-on-metal hip implants; 2015. p. 3-5. website: http://www.fda. gov/MedicalDevices/ProductsandMedicalProcedures/Implantsa
ndProsthetics/MetalonMetalHiplmplants/ucm241604.htm (Accessed 10 Apr 2018)

10. Government of Canada. Metal-on-metal hip implants - Information for Orthopaedic Surgeons regarding patient management following surgery For health professionals; 2012. p. 1-4. website: http://healthycanadians.gc. ca/recall-alert-rappel-avis/hc-sc/2012/15835a-eng.php?_ga=2.73829074.1 764429604.1523352710-823890699.1523352710 (Accessed 10 Apr 2018)

11. Langton DJ, Jameson SS, Joyce TJ, Hallab NJ, Natu S, Nargol AVF. Early failure of metal-on-metal bearings in hip resurfacing and large-diameter total hip replacement: a consequence of excess wear. J Bone Jt Surg - Br Vol. 2010;92-B(1):38-46. https://doi.org/10.1302/0301-620X.92B1.22770.

12. Bozic KJ, Kurtz S, Lau E, Ong K, Chiu V, Vail TP, et al. The epidemiology of bearing surface usage in total hip arthroplasty in the United States. J Bone Jt Surg - Ser A. 2009;91(7):1614-20. https://doi.org/10.2106/JBJS.H.01220.

13. Danish Medicines Agency. Metal-metal hip arthroplasties 2012. https://la egemiddelstyrelsen.dk/da/udstyr/orientering/metal-metal-hofteproteser/ (Accessed 3 Jan 2019).

14. Mahomed NN, Arndt DC, McGrory BJ, Harris WH. The Harris hip score: comparison of patient self-report with surgeon assessment. J Arthroplast. 2001;16(5):575-80. https://doi.org/10.1054/arth.2001.23716.

15. Ware JE, Snow KK, Kosinski M, Gandek B. SF-36 Health Survey Manual \& Interpretation Guide. Boston: The Health Institute, New England Medical Center; 1993.

16. DeLee JG, Charnley J. Radiological demarcation of cemented sockets in total hip replacement. Clin Orthop Relat Res. 1976;(121):20-32.

17. Gruen TA, McNeice GM, Amstutz HC. "Modes of failure" of cemented stemtype femoral components: a radiographic analysis of loosening. Clin Orthop Relat Res. 1979;(141):17-27.

18. Callanan MC, Jarrett B, Bragdon CR, Zurakowski D, Rubash HE, Freiberg AA et al. The john charnley award: risk factors for cup malpositioning: quality improvement through a joint registry at a tertiary hospital. Clin Orthop Relat Res. 2011;469(2):319-29. https://doi.org/10.1007/s11999-010-1487-1.

19. Overgaard S, Ovesen O, Penny J, Ulrich-Vinther M, Stürup J. Udredningsprogram: Metal on Metal hoftealloplastik n.d. https://www. ortopaedi.dk/fileadmin/nyhedsbrev/nov2010/Final_MoM_adhocudvalg_27okt-2010.pdf (Accessed 20 Jan 2020).

20. Bjørner JB, Damsgaard MT, Watt T, Bech P, Rasmussen NK, Kristensen TS, et al. Dansk manual til SF-36 (Danish manual for SF-36). Copenhagen: Lif; 1997.

21. Borgwardt A, Borgwardt L, Zerahn B, Daugaard H, Borgwardt L, RibelMadsen S. A randomized seven-year study on performance of the stemmed metal M2a-magnum and ceramic C2a-taper, and the resurfacing ReCap hip implants. J Arthroplast. 2018;33(5):1412-20. https://doi.org/10.1016/j.arth.201 7.11.061.

22. Costa ML, Achten J, Parsons NR, Edlin RP, Foguet P, Prakash U, et al. Total hip arthroplasty versus resurfacing arthroplasty in the treatment of patients with arthritis of the hip joint: single centre, parallel group, assessor blinded, randomised controlled trial. Bmj. 2012;344(apr19 1):e2147. https://doi.org/1 0.1136/bmj.e2147.

23. Garbuz DS, Tanzer M, Greidanus NV, Masri BA, Duncan CP. The john charnley award: metal-on-metal hip resurfacing versus large-diameter head metal-on-metal total hip arthroplasty: a randomized clinical trial. Clin Orthop Relat Res. 2010;468(2):318-25. https://doi.org/10.1007/s11999-009-1029-x.

24. Khan M, Kuiper JH, Sieniawska C, Richardson JB. Differences in concentration of metal debris in blood, serum, and plasma samples of patients with metal-on-metal hip resurfacing arthroplasty. J Orthop. 2016; 13(4):450-4. https://doi.org/10.1016/j.jor.2015.10.006.

25. Jantzen C, Jørgensen HL, Duus BR, Sporring SL, Lauritzen JB. Chromium and cobalt ion concentrations in blood and serum following various types of metal-on-metal hip arthroplasties: a literature overview. Acta Orthop. 2013; 84(3):229-36. https://doi.org/10.3109/17453674.2013.792034.

26. Renner L, Faschingbauer M, Schmidt-Braekling T, Boettner F. Cobalt serum levels differ in well functioning Birmingham resurfacing and Birmingham modular THA. Arch Orthop Trauma Surg. 2016;136(5):715-21. https://doi. org/10.1007/s00402-016-2439-3.

27. Hutt J, Lavigne M, Lungu E, Belzile E, Morin F, Vendittoli PA. Comparison of whole-blood metal ion levels among four types of large-head, metal-onmetal total hip arthroplasty implants. J Bone Jt Surg - Am. 2016;98(4):25766. https://doi.org/10.2106/JBJS.0.00201.

28. Jacobs JJ, Skipor AK, Patterson LM, Hallab NJ, Paprosky WG, Black J, et al. Metal release in patients who have had a primary total hip arthroplasty. A 
prospective, controlled, longitudinal study. J Bone Joint Surg Am. 1998; 80(10):1447-58. https://doi.org/10.2106/00004623-199810000-00006

29. Berstock JR, Whitehouse MR, Duncan CP. Trunnion corrosion: what surgeons need to know in 2018. Bone Jt J. 2018;100B(1_Supple_A):44-9. https://doi. org/10.1302/0301-620X.100B1.BJJ-2017-0569.R1.

30. Borgwardt A, Borgwardt LL, Zerahn B, Daugaard H, Borgwardt LL, Ribel-Madsen $\mathrm{S}$. A randomized seven-year study on performance of the stemmed metal M2amagnum and ceramic C2a-taper, and the resurfacing ReCap hip implants. J Arthroplast. 2017;33(5):1-9. https://doi.org/10.1016/j.arth.2017.11.061.

31. Varnum C, Pedersen AB, Mäkelä K, Eskelinen A, Havelin LI, Furnes $O$, et al. Increased risk of revision of cementless stemmed total hip arthroplasty with metal-on-metal bearings. Acta Orthop. 2015;86(4):491-7. https://doi.org/1 $0.3109 / 17453674.2015 .1023132$

32. Junnila M, Kostensalo I, Virolainen P, Remes V, Matilainen M, Vahlberg T, et al. Hip resurfacing arthroplasty versus largediameter head metal-on-metal total hip arthroplasty: comparison of three designs from the finnish arthroplasty register. Scand J Surg. 2014;103(1):54-9. https://doi.org/10.11 77/1457496913495345

33. Jack CM, Walter WL, Shimmin AJ, Cashman K, de Steiger RN. Large diameter metal on metal articulations. Comparison of Total hip Arthroplasty and hip resurfacing Arthroplasty. J Arthroplast. 2013;28(4):650-3. https://doi.org/10.1 016/j.arth.2012.07.032.

\section{Publisher's Note}

Springer Nature remains neutral with regard to jurisdictional claims in published maps and institutional affiliations.

Ready to submit your research? Choose BMC and benefit from:

- fast, convenient online submission

- thorough peer review by experienced researchers in your field

- rapid publication on acceptance

- support for research data, including large and complex data types

- gold Open Access which fosters wider collaboration and increased citations

- maximum visibility for your research: over $100 \mathrm{M}$ website views per year

At $\mathrm{BMC}$, research is always in progress.

Learn more biomedcentral.com/submissions 